\title{
Consumer's Preference and Awareness: Comparative Analysis between Conventional and Islamic ljarah Auto Financing in Pakistan
}

\author{
Imran Umer Chhapra ${ }^{1}$, Afzal Ahmed ${ }^{2}$, Raja Rehan ${ }^{3}$, Farasat Hussain ${ }^{4}$
}

\begin{abstract}
A healthy banking industry plays a vital role in the economic stability, and banks success depends on its products. Therefore, this study aims at cognizing the consumer's preference and awareness of Islamic Ijarah over the conventional lease in Pakistan. This research used regression as tools of analysis. The findings indicate that convenience is the prime determinant for preference of Ijarah over the lease. Moreover, all other factors except religion also support in the motivate selection of Islamic banking products. Therefore, it can be concluded that in Pakistan, religion is not the only fact motivates individuals to prefer Ijarah. Based on findings, it is recommended to relevant stakeholders to create more awareness among masses about Ijarah and to further ease out policies in order to harness optimum benefit.
\end{abstract}

Keywords: consumer preference, Islamic Ijarah auto financing, conventional auto financing

\begin{abstract}
Abstrak. Industri perbankan yang sehat memainkan peran penting dalam stabilitas ekonomi dan keberhasilan bank tergantung pada produknya. Oleh karena itu, penelitian ini bertujuan untuk mengetahui preferensi dan kesadaran konsumen terhadap akad Ijarah Islam atas sewa konvensional di Pakistan. Penelitian ini menggunakan regresi berganda sebagai alat analisis. Temuan menunjukkan bahwa kenyamanan adalah penentu utama untuk preferensi Ijarah atas sewa. Selain itu, semua faktor lain kecuali agama juga mendukung pemilihan produk perbankan Islam. Oleh karena itu, dapat disimpulkan bahwa di Pakistan, agama bukanlah satu-satunya faktor yang memotivasi individu untuk memilih Ijarah. Berdasarkan temuan, direkomendasikan kepada pemangku kepentingan yang relevan untuk menciptakan kesadaran di antara massa tentang Ijarah dan untuk lebih memudahkan kebijakan guna memanfaatkan manfaat optimal.
\end{abstract}

Keywords: preferensi konsumen, pembiayaan mobil syariah, pembiayaan mobil konvensional

\section{How to Cite:}

Chhapra, I. U., Ahmed, A., Rehan, R., \& Hussain, F. (2018). Consumer's Preference and Awareness: Comparative Analysis Between Conventional and Islamic Ijarah Auto Financing in Pakistan. AlIqtishad: Jurnal Ilmu Ekonomi Syariah (Journal of Islamic Economics). Vol. 10 (2): 389 - 402. doi: http://dx.doi.org/10.15408/aiq.v10i2.7106. 


\section{Introduction}

Financial sector plays a very vital role in the economic progress on any country and it is considered as the backbone of the economy. Hence, stronger economic system is dependent on healthy banking system of the country (Srouji, et al 2015). There are two main modes of banking systems, one is called Islamic banking and the alternative is conventional banking. Both modes of banking differ from each other in many ways and offer different financial products for the consumer. If we compare with the other different banking products, auto financing or car leasing is one of the important products of consumer financing which facilitates banks to generate huge amount of revenue and maintain healthy banking relationship with their customers.

In Islamic banking, the lease is named as Ijarah. Ijarah is the Shariah law compliant version of conventional lease. In both forms of lease (Ijarah and conventional) bank acts as Lessor (lease giver) and the party to whom the service, benefit or asset is given is called Lessee (lease taker). The lessor asks the lessee to pay periodic rentals for reaping or enjoying lease benefits and the ownership remains with the lessor, solely the rights of use is transferred to lessee. Ijarah could be a term of monotheism Fiqh. Lexically, it means that 'to offer one thing on rent'. Within the monotheism jurisprudence, the term 'Ijarah' is employed for two totally different concepts. Within the first place, it means that 'to use the services of an individual on wages given to him as a thought for his employed services.' The leader is named Musta'jir whereas the worker is named Ajir. This kind of Ijarah includes each group action wherever somebody else employs the services of an individual.

The second kind of Ijarah relates to the usufructs of assets and properties, and to not the services of men. 'Ijarah' in this sense means that 'to transfer the legal right of a selected property to a different person in exchange of rent claimed from him.' In this case, the term 'Ijarah' is similar to English term 'leasing'. Here, the owner is named 'Mu'jir', the leaseholder is named 'Musta'jir' and the rent collectible to the owner is named 'Ujrah'. Both these types of 'Ijarah' are mentioned within the literature of monotheism jurisprudence and both of them have their own set of rules.

The second kind of Ijarah is a lot of relevant, because of its usually used as a sort of investment, and as a mode of finance additionally. The rules of Ijarah, within the sense of leasing, is incredibly abundant analogous to the foundations of sale, because of in each case one thing is transferred to a different person for a valuable thought. The sole distinction between Ijarah and sale is that within the latter case the corpus of the property is transferred to the vendee, whereas within the case of Ijarah, the corpus of the property remains within the possession of the transferred, however solely its legal right i.e. the correct to use it, is transferred 
to the leaseholder. Therefore, it will simply be seen that 'Ijarah' isn't a mode of finance in its origin. It's a traditional endeavor like sale. However, attributable to bound reasons, and especially, attributable to some tax concessions it's going to carry, this group action is getting used within the Western countries for the aim of finance additionally. Rather than giving a straightforward interest - bearing loan, some money establishments started leasing some equipment's to their customers. Whereas fixing the rent of those instrumentation, they calculate the whole value they need incurred within the purchase of those assets associated add the stipulated interest they might have claimed on such a quantity throughout the lease amount. The mixture quantity therefore calculated is split on the whole months of the lease amount, and the monthly rent is fastened thereon basis.

On the other hand, in typical conventional finance, lenders lend to borrowers to form cash in on the interest charged on the principal quantity. For property loans, borrowers pay associate interest on the outstanding principal quantity. Interest rates may be a set rate or support a floating rate (e.g. KIBOR, LIBOR). Payment is formed over collection tenure by installments. Since the contract isn't supported associate definite quantity (e.g. an acquisition price), the earlier the receiver will pay down the principal, the cheaper the quantity of interest paid. The loan contract for typical finance is understood as a loan facility agreement. Benefits of conventional financing over Islamic financing are for conventional loans, if a borrower alters the terms of the finance (e.g. Increase the facility amount), the loan facility agreement would only need to be up-stamped. For Islamic financing, a new sale and buyback agreement (BBA) needs to be drawn up, making it more expensive. Moreover, Islamic financing has difficulty in restructuring or refinancing in the case of default whereas costs for early settlements, late payments or defaults are more transparent in case of conventional financing. Anyone (not just Muslims) can take up Islamic financing. But if your occupation is not deemed "halal", there could be difficulty in obtaining the loan. For details see in Table 1.

Islamic banking is gaining popularity all around the world especially in the emerging economies like Pakistan. The main reason is Islamic banking helped many financial institutions and investors to avoid the worst of economic meltdowns as conventional banks were more affected by global economic recession. This is mainly because Islamic banks have not been exposed to losses from investment in toxic assets nor have they been dependent on wholesale funds since these practices are not in accordance with the principles set out in the Sharia Law (Chhapra, and Bhutto, 2013). Therefore the underlying principle for this study is to critically identify the different factors that led the consumers to prefer Islamic mode of automobile financing and what is the basic difference between conventional auto 
financing and Ijarah financing. Moreover, which mode of automobile financing best accommodates the needs of consumers?

Table 1. Difference between Lessee and Ijarah

\begin{tabular}{|c|c|c|}
\hline Differences & Conventional Auto Financing & Islamic Ijarah Financing \\
\hline Terminology & Lease, Lessor and Lessee & Ijarah, Aajir and Ajir \\
\hline Rent & Starts from the date of agreement & $\begin{array}{l}\text { Starts when asset is delivered to } \\
\text { the customer }\end{array}$ \\
\hline Mode & Money is given as loan & Asset is bought on behalf of client \\
\hline Profit & Interest is charged on loan amount & $\begin{array}{l}\text { Rent is charged as share of the } \\
\text { bank in the asset }\end{array}$ \\
\hline Risk Management & $\begin{array}{l}\text { Risk of leased asset in minimize } \\
\text { through insurance }\end{array}$ & $\begin{array}{l}\text { Risk of leased asset is minimize } \\
\text { through Takaful }\end{array}$ \\
\hline Penalty & $\begin{array}{l}\text { The bank charged penalty for non- } \\
\text { payment or late payment }\end{array}$ & $\begin{array}{l}\text { The bank charged penalty for } \\
\text { non-payment or late payment and } \\
\text { pay that amount as charity }\end{array}$ \\
\hline
\end{tabular}

Source: Razi (2014)

\section{Literature Review}

Islamic leasing or Ijarah financing is one of the emerging phenomenon of the present time, as common people are getting awareness about Islamic banking products, they are more likely to be attracted towards it. Several studies have been conducted throughout the world to assess consumer's review and opinion about the Islamic Banking products and Ijarah Financing.

Razi, (2014), extensively studied the Islamic banking system within the context of Pakistan. The researcher investigates the Islamic mode of finance and leasing, in the light of Shariah, which is based on the concept of Ijarah, Mubarha and Musharika that facilitates the consumers. He conducted a comparative analysis for mode of leasing between conventional and Islamic banks and revealed that under developed individuals who lacks adequate financial resources cannot avail the services of Islamic banking and the total cost of Ijarah Financing is not different with the cost of conventional leasing, thus have no cost benefit to consumer.

Moreover, a critical analysis focusing on the proponent and opponent of Islamic banking practices in Pakistani context has been analyzed by Zubair, \& Chaudhary, (2014), who studied the Islamic Banking practices in empirical sense. The researchers studied the theories of Islamic Banking in Shariah and 
Jurisprudence and investigated the existing practices of Islamic Banking in Pakistan. Upon attempting to explore similarities and dissimilarities between conventional and Islamic Banking Practices in Pakistan, the researchers established the view that existing system, policies and procedure of Islamic Banking in Pakistan is not adhering its original objective. According to observation and finding of researchers, the existing system of Islamic Banking in Pakistan is based of inappropriate and deceptive tricks which misrepresents the face of Islamic Banking in front of general consumers and also the actual objectives of implementing Islamic Banking according to the Shariah have been severely destructed. The researchers claimed that both Islamic and conventional bank deals in money and do not participate in any form of business or trade and both of the banking modes are having similar base.

Similarly, the study about the awareness and satisfaction of Islamic banking system had done by Zaher and Hassan (2001). The findings of the research revealed that customers are aware of Islamic banking products and services but do not use them as they are not fully customers satisfied with bank's services. Khattak and Rehman, (2010) and Karim (2012) also researched on the same subject and found that customers are aware about Islamic Banking practices and system but they are not likely to be dealing with Islamic Banking products and services. With the aim to build perception and raise awareness of Islamic banking products among Pakistani customers, a study by (Masood, et al, 2014) was conducted to cognize the consumer awareness and perception of Islamic Banking products in Pakistan, the study was qualitative and exploratory, where semi structure interviews were conducted to estimate the consumer's level of understanding of Islamic Shariah compliant banking products and services. Analysis and findings reveals that neither customer nor bankers have complete awareness of Islamic banking products and services as customers generally and mostly use only checking accounts (current and saving) and not utilize different Islamic financing modes.

On the other hand, due to its beneficial features, like tax advantage and efficient approval process, lease financing became an attractive source of financing and leasing industry have achieved a remarkable growth in Pakistan through the years. Therefore, the financial performance of leasing industry of Pakistan has been studies and analyzed by various researchers like Raza, et al (2011) conducted ratio analysis to analyze profitability, equity, and leverage of all leasing companies in Pakistan. The findings explains that from 2007 to 2009, number of leasing companies declined because of number of reasons particularly high cost of financing and provisioning, economic slowdowns and non-compliance of minimum equity requirements set out by SECP, after 2009 to 2010 the financial performance of leasing industry regained its growth and performed better. 
Furthermore, major issues and challenges of consumer financing in Pakistan according to consumer's perception is examined by Hassan (2011), who analyzed the economic and procedural factors impacting the decision of a consumer to get the loan from bank. There are number of challenges identified by the researcher that impact negatively on the image of consumers financing Pakistan are complaint of consumers related to processing delays, hidden charges, service inefficiencies and poor disclosure practices. However, Consumer financing have achieved remarkable growth in last seven years in Pakistan, major banks have exclusively capitalized their revenues and profits by advancing financing facility to consumers as per credit policy stipulated by State Bank of Pakistan. Despite its success, major banks were appeared to be failed to comply with SBP regulations in servicing and satisfying consumers against different factors such as variable interest rates, difference between lending and deposit rates, poor disclosure, hidden charges, inefficient service and procedural delays (Hassan, 2011).

In Malaysia, Abdullah and Dusuki (2006), have studies thoroughly about Islamic Hire-Purchase agreement that is one type of Islamic Ijarah financing. They analyzed consumer's perception and awareness about Islamic Hire-Purchase financing in Malaysia, the finding shows a very strong and positive outlook from people of Malaysia for the Islamic Ijarah Financing and they support the idea of owning the asset specifically automobile through the channel of Islamic HirePurchase agreement. Similarly, the impact of demographic factors on consumer perception and awareness toward Islamic automobile financing was investigated in two cities of Malaysia, Labuan and Kota Kinabalu by (Amin, 2007). The findings reveal that demographic factors are prominent indicators in identifying the difference for Islamic Ijarah Automobile Financing on individual level, as there are significant differences found in opinion of bank customer about Islamic Ijarah Automobile Financing according to the demographic factors.

In addition, awareness of Islamic banking products among non-Muslims are also measured by various researchers. (Ling, et al, 2012) analyzed the performance and potential of Islamic Banking among people of Malaysia. The result showed that most of the Non-Muslims of Malaysia were aware about the name of Islamic Banking but do not aware about the details of products and services it offers, researcher quote the possible reason of non-awareness is the language gap as products and services offered by Islamic Banks and termed in Arabic language. Likewise, the perception and awareness of Islamic Banking products were also tested in Kazakhstan by (Abduh and Omarov, 2013) and concluded that people of Kazakhstan are aware about Islamic Banking but not have knowledge about the products and services, besides this, the willingness to avail services and products of Islamic Banking was 
found to be very high. Idris, et al., (2011) conducted a study to identify the most important factor in patronizing customers for Islamic Banks and the findings identified religious values as foremost and important factor which influence the decision of bank's customer and stimulate the preference to go for Islamic banking services but Erol and El-Bdour (1989) indicated that religious values and motives are not the only driving factor and bank customers are profit motivated, and the impact of peer group plays a vital role in patronizing bank customers to prefer Islamic bank as depository institution.

\section{Method}

As this study aims to analyze consumer's perception and awareness about conventional automobile financing and Islamic Ijarah financing, therefore this research has been classified as descriptive study. This research rely on primary data consists of responses from Pakistani automobile consumers collected by incorporating questionnaire survey methodology. The automobile consumers in Pakistan are the population of this study in general and consumers from different occupations and professions are selected as a sample. The responses of automobile consumers are analyzed through quantitative analysis tools. By considering the objective and research problem of this study, simple probability random sampling method has been used to collect a sample of 200 current and prospective consumers.

As described earlier that this study relies on two sort of data, the primary data which would comprise of the responses of different automobile consumers and the secondary data which consists of past literature, that has been referred in analysis and preparation of literature First, reliability and validity of questionnaire is checked using Cronbach's Alpha and then the primary data is analyzed using descriptive to explain the demographics of sample and finally, inferential statistical techniques like correlation, ANOVA and regression analysis is conducted to draw conclusions from collected data.

This research will procure insight and observation for consumers' preference for Ijarah financing over conventional lease in Pakistan. Awareness, perception, religion, income and convenience are the independent factors that might lead to preference of Ijarah over lease in Pakistan. Therefore, empirical model that has been tested in this paper is:

$$
\mathrm{CP}=\beta_{0}+\beta_{1} \text { Awr }+\beta_{2} \text { Per }+\beta_{3} \operatorname{Reg}+\beta_{4} \operatorname{Inc}+\beta_{5} \operatorname{Con}+\mu
$$

Where, CP is consumer preference, Awr is awareness, Per is perception, Reg is religion, Inc is income and Con is convenience. 


\section{Results and Discussion}

As discussed earlier, that gathering responses from different consumers collects data, a total of 200 Questionnaire were distributed electronically among different current and prospective automobile consumers of Pakistan. From 200 distributed questionnaires, only 170 have responded and gave their review. From 170 collected questionnaires, only 142 questionnaires were filled completely and properly therefore the response rate of this study is $71 \%$.

Table 2 shows the profile of automobile loan consumers (respondents). We can see the respondent profile from some aspects, such as: gender, age, religion, qualification, occupation, and income

Table 2. Respondents' Profile

\begin{tabular}{|c|c|c|c|}
\hline Variable & & Frequency & Percentage \\
\hline \multirow[t]{2}{*}{ Gender } & Male & 118 & $83.1 \%$ \\
\hline & Female & 24 & $16.9 \%$ \\
\hline \multirow[t]{4}{*}{ Age } & Less than 25 & 53 & $37.3 \%$ \\
\hline & Between $26-35$ & 54 & $38.0 \%$ \\
\hline & Between $36-45$ & 24 & $16.9 \%$ \\
\hline & 45 and above & 11 & $7.7 \%$ \\
\hline \multirow[t]{2}{*}{ Religion } & Muslim & 127 & $89.4 \%$ \\
\hline & Non-Muslim & 15 & $10.6 \%$ \\
\hline \multirow[t]{4}{*}{ Qualification } & Matriculation & 2 & $1.4 \%$ \\
\hline & Intermediate & 4 & $2.8 \%$ \\
\hline & Graduation & 53 & $37.3 \%$ \\
\hline & Post-Graduation & 83 & $58.5 \%$ \\
\hline \multirow[t]{4}{*}{ Occupation } & Self Employed & 10 & $7.0 \%$ \\
\hline & Salaried Individuals & 112 & $78.9 \%$ \\
\hline & Non-Salaried Individuals & 2 & $1.4 \%$ \\
\hline & Unemployed/Student & 18 & $12.7 \%$ \\
\hline \multirow[t]{5}{*}{ Income (Rs.) } & Less than 15,000 & 22 & $15.5 \%$ \\
\hline & 15,001 to 35,000 & 40 & $28.2 \%$ \\
\hline & 35,001 to 55,000 & 45 & $31.7 \%$ \\
\hline & 55,001 to 75,000 & 23 & $16.2 \%$ \\
\hline & More than 75,001 & 12 & $8.5 \%$ \\
\hline
\end{tabular}


To analyze the reliability of the collected data, 22 core variables were tested; the value of Cronbach's Alpha is found to be 0.660 that is greater than 0.65 , which shows that the data is found to accurate and reliable. The result can be seen in Table 3. The validity of the questionnaire was established by discussing the contents of the questionnaire of experts of Islamic Ijarah financing and conventional automobile financing.

Table 3. Reliability Testing

\begin{tabular}{cc}
\hline Cronbach's Alpha & N of Items \\
\hline .660 & 22 \\
\hline
\end{tabular}

To ascertain the normality of the variables, the results of descriptive analysis are presented in Table 4 . Table 4 shows that the values of kurtosis ranged between (1.81 to -0.09$)$. It was highest for perception $(\mathrm{Mean}=4.42, \mathrm{SD}=1.81)$, and the lowest for consumer preference (Mean $=4.40, S D=1.25$ ). Additionally, the highest skewness value $(-1.30)$ was for awareness (Mean $=3.44, \mathrm{SD}=1.71)$, and the lowest for convenience $(\mathrm{Mean}=3.87, \mathrm{SD}=1.65)$. As all the skewness and kurtosis values are between \pm 3.5 ,

Table 4. Descriptive Analysis

\begin{tabular}{ccccc}
\hline Variable & Mean & Standard Deviation & Skewness & Kurtosis \\
\hline Awareness & 3.44 & 1.71 & -1.30 & 0.53 \\
Perception & 4.42 & 1.81 & -0.58 & 1.81 \\
Religion & 3.95 & 1.33 & -0.91 & 0.37 \\
Income & 4.16 & 1.40 & -0.43 & -1.22 \\
Convenience & 3.87 & 1.65 & 0.18 & 0.53 \\
Consumer Preference & 4.40 & 1.25 & -0.86 & -0.09 \\
\hline
\end{tabular}

Correlation coefficient depicts the extent of relationship among target variables; it also shows the movement of variables related to each other. In Table 5, the value of correlation between perception and preference is 0.067 , which shows that there is very weak but positive relationship between perception and consumer's preference. The value of correlation between awareness and preference is 0.119, which shows that there is weaker but positive relationship between awareness of 
respondents and their consumer's preference. The correlation between income level and preferences and religion and preference show weak negative correlation - 0.043 and -0.159 respectively.

Table 5. Correlation Analysis

\begin{tabular}{lcccccc}
\hline Variables & CP & AWR & PER & REG & INC & COn \\
\hline Consumer Preference (CP) & 1 & & & & & \\
Awareness (AWR) & .119 & 1 & & & & \\
Perception (PER) & .067 & $.361^{* *}$ & 1 & & & \\
Religion (REG) & -.159 & $.368^{* *}$ & .115 & 1 & & \\
Income (INC) & -.043 & $.620^{* *}$ & $.344^{* *}$ & $.387^{* *}$ & 1 & \\
Convenience (CON) & .013 & .090 & $.380^{* *}$ & .081 & .541 & 1 \\
\hline
\end{tabular}

**. Correlation is significant at the 0.01 level (2-tailed).

The result of regression analysis (Table 6) shows that there is moderate relationship between dependent and independent variables as explanatory variables explain $37.1 \%$ variation in explained variable. Moreover, from the results it can be observed awareness about Islamic banking products, perception of dealing in Shariah base products, Halal investment and income and easiness and convenience of availability of Islamic Ijarah show significant motivation behind the preference of Ijarah over conventional lease. Our results are consistent with the findings of Kaufman (1967), Mason and Mayer (1974), Martenson (1985), Laroche et al. (1986) and (Srouji, Halim and Lubis, 2015).

Table 6. Regression Analysis

\begin{tabular}{ccc}
\hline Model & Coefficient & P-value \\
\hline Constant & 1.871 & 0.021 \\
Awareness & -0.513 & 0.013 \\
Perception & 0.435 & 0.000 \\
Religion & 0.341 & 0.007 \\
Income & 0.383 & 0.020 \\
Convenience & 1.023 & 0.000 \\
\hline
\end{tabular}

$R^{2}=0.371 ;$ Adjusted $R^{2}=0.243$, F-value $=13.801$ 
On the other hand, findings indicate that religion has no significant role in preference of Ijarah over conventional lease in Pakistan, which contradicts the outcomes of Omer (1992), Hegazy (1995), Bashir (1999), Naser et al. (1999), Ahmed and Haron (2002), Dusuki and Abdullah (2007). But, this result is similar to findings of Erol and El-Bdour (1989), Gerrard and Cunningham (1997) and Zaher and Hassan (2001).

The growth and prospect of Islamic Ijarah Financing in banking sector of Pakistan was assessed by Sabir (2008) and found that Islamic Ijarah Financing is increasingly growing than conventional financing due to its interest free nature and its compliance with Islamic Shariah Rules. Similarly, (Rizwanllah, et al, 2012) critically reviewed automobile Ijarah financing in Pakistan. The results showed that Islamic Automobile Ijarah financing offered by banks is not complying the Islamic Shariah guidelines and principles completely, because there are some discrepancies in the process. Moreover, a comparative analysis between Islamic Ijarah financing and conventional leasing was conducted by Sabir (2008) and proposed that by employing different Shariah compliant Islamic products, Islamic financial markets can be effectively captured. Naqvi, and Perveen, (2014) analyze the growth of Ijarah investment in Pakistan and their findings showed that there is a strong positive association between dependent and independent variables, therefore it was concluded that deposit and other account, and share capital have an impact on Net Ijarah Investment and its growth.

\section{Conclusion}

The research was aimed to analyze the awareness level and their preference regarding Islamic Ijarah Financing over conventional automobile financing in Pakistan. From the result it can be concluded that easy and convenience of availability of Islamic banking products including Ijarah due to continuous growth in Islamic banks and Islamic windows of conventional banks is the prime motivate behind preference of Islamic Ijarah over conventional lease in Pakistan. Avkiran (1999) found similar results where he concluded that easy access is the discriminating factor behind Islamic bank selection. Moreover, other factors like awareness about Ijarah benefits, perception of Shariah compliant products and Halal income and investment are also the important factors that affects individual decision to choose Islamic Ijarah financing over conventional automobile financing in Pakistan. On the hand, results of our study suggest that religion is not the key determinant in preference of Ijarah over lease in Pakistan. Our study also found support from previous researches like Erol and El-Bdour (1989), Gerrard and Cunningham (1997) and Zaher and Hassan (2001) as they 
concluded that religion is not the sole criteria for selection of Islamic banking products.

From this study, it is found that there is confusion and lack of proper awareness and knowledge about financing/leasing option of acquiring automobile among consumers, also respondents were also not properly aware about the distinction between conventional auto financing and Islamic Ijarah auto financing, therefore it is strongly recommended to the educational institutes, central bank, commercial and Islamic banks and TV Channels to create awareness about Islamic Ijarah Auto Financing and its benefit to the general public and central bank should also make such policies which favors the consumers to acquire automobile through financing/ leasing option.

The results of this research would have implication on Islamic banks offering Ijarah automobile financing as how they can improve the quality of service in growing better awareness among consumers. Moreover, further studies could be conducting by focusing on other products and services of the bank like Mudarbah, Musharika, Islamic Trade Finance, Islamic Entrepreneurial Finance, etc. and their perception and awareness among masses.

\section{References}

Abduh, M., \& Omarov, D. (2013). Muslim's Awareness and Willingness to Patronize Islamic Banking in Kazakhstan. Journal of Islamic Banking and Finance. Vol. 30 (3): 16-24.

Abdullah, N. I., \& Dusuki, A. W. (2006). Customers' Perceptions of Islamic Hire-Purchase Facility in Malaysia: An Empirical Analysis. IIUM Journal of Economics and Management. Vol. 14 (2): 177-204.

Ahmad, N., \& Haron, S. (2002). Perceptions of Malaysian Corporate Customers Towards Islamic Banking Products and Services. International Journal of Islamic Financial Services. Vol. 3(4): 13-29.

Amin, H. (2007). Borneo Islamic Automobile Financing: Do Demographics Matter? Labuan e-Journal of Muamalat and Society. Vol. 1: 68-81.

Avkiran, N.K. (1999). Quality Customer Service Demands Human Contact. International Journal of Bank Marketing. Vol. 17(2): 61-74.

Bashir, A. (1999). Risk and Profitability Measures in Islamic Banks: The Case of Two Sudanese Banks. Islamic Economic Studies. Vol. 6: 1-24.

Chhapra, I. U., \& Bhutto, S. (2013). An Empirical Investigation on Perception of Post-Graduate Students towards Islamic Finance in Islamic Republic Of Pakistan. Asian Journal of Research in Banking and Finance. Vol. 3(12): 68-80. 
Dusuki, A. W., \& Abdullah, N. I. (2007). Why Do Malaysian Customers Patronise Islamic Banks?. International Journal of Bank Marketing. Vol. 25(3): 142-160.

Erol, C., \& El-Bdour, R. (1989). Attitudes, Behaviour, and Patronage Factors of Bank Customers towards Islamic Banks. International Journal of Bank Marketing. Vol. 7(6): 31-37.

Gerrard, P., \& Cunningham, J. B. (1997). Islamic Banking: a Study in Singapore. International Journal of Bank Marketing. Vol. 15(6): 204-216.

Hassan, N. (2011). Issues and Challenges of Consumer Financing in Pakistan. (Unpublished Master Thesis). Sweden: University West.

Hegazy, I. (1995). An Empirical Comparative Study Between Islamic and Commercial Banks' selection criteria in Egypt. International Journal of Commerce \& Management. Vol. 5(3): 46-61.

Idris, R. A., Naziman, K. N., Januri, S. S., Asari, F. A., Muhammad, N., Sabri, S. M., \& Jusoff, K. (2011). Religious Value as the Main Influencing Factor to Customers Patronizing Islamic Bank. World Applied Sciences Journal. Vol. 12 (Special Issue on Bolstering Economic Sustainability): 8-13.

Karim, F. (2012). Customer Satisfaction and Awareness of Islamic Banking Products and Services in Pakistan. Interdisciplinary Journal of Contemporary Research in Business. Vol. 4(4): 384-401.

Kaufman, G.G. (1967). A Survey of Business Firms and Households View of a Commercial Bank. Report to the Federal Reserve Bank of Chicago. Appleton: University of Wisconsin, Madison, WI.

Khattak, N. A., \& Rehman, K. U. (2010). Customer Satisfaction and Awareness of Islamic Banking System in Pakistan. African Journal of Business Management. Vol. 4(5): 662-671.

Laroche, M., Rosenblatt, J., \& Manning, T. (1986). Services Used and Factors Considered Important in Selecting a Bank: an Investigation Across Diverse Demographic Segments. International Journal of Bank Marketing. Vol. 4(1): 35-55.

Ling, K. L., Ling, K. M., Pey, L. S., \& Hui, Z. W. (2012). Awareness of Islamic Banking Products and Services among Non-Muslims in Malaysia. (Unpublished Bachelor Thesis). Malaysia: Universiti Tunku Abdul Rahman.

Martenson, R. (1985). Consumer Choice Criteria in Retail Bank Selection. International Journal of Bank Marketing. Vol. 3(2): 64-75.

Mason, J.B., \& Mayer, M. L. (1974). Differences Between High-and-LowIncome Savings and Checking Account Customers. The Magazine of Bank Administration. Vol. 65: 48-52. 
Masood, S., Rehman, S., \& Rehman, C. A. (2014). Cognizing Customer Awareness and Perception of Islamic Banking Products in Pakistan. International Journal of Operations and Logistics Management. Vol. 3(4): 322-336.

Naqvi, N. A., \& Perveen, A. (2014). Analysis of Growth of Ijara Investment in Pakistan. KASBIT Business Journal (KBJ). Vol. 7(2): 21-34.

Naser, K., Jamal, A., \& Al-Khatib, L. (1999). Islamic Banking: a Study of Customer Satisfaction and Preferences in Jordan. International Journal of Bank Marketing. Vol. 17(3): 135-50.

Omer, H. (1992). The Implications of Islamic Beliefs and Practice on the Islamic Financial Institutions in The UK: Case Study of Albaraka International Bank UK. (Unpublished Dissertation). Leicestershire: Loughborough University.

Raza, A., Akram, M., \& Alam, H. M. (2011). Financial Performance of Leasing Sector. The Case of Pakistan. Interdisciplinary Journal of Contemporary Research in Business. Vol. 2(12): 339-345.

Razi, N. (2014). Islamic Banking System and Mode of Leasing: A Comparative Analysis in the Light of Maqasid al-Shari'ah. Cultural and Religious Studies. Vol. 2(6): 349-359

Rizwanullah., Ullah, I., Khan, M., Ali, A., \& Shah, F. A. (2012). A Critical Review of Car Ijarah in Pakistan: A Case Study of Car Ijarah Offered by Meezan Bank Limited Pakistan. Retrieved from: https:/www.researchgate.net/ publication/254935510_A_Critical_Review_of_Car_Ijarah_in_Pakistan_A_ Case_Study_of_Car_Ijarah_Offered_by_Meezan_Bank_Limited_Pakistan

Sabir, S. (2008). Prospects of Ijarah in Banking Sector of Pakistan. Retrieved from SSRN: https://ssrn.com/abstract=1308826.

Srouji, A. F., Halim, M. S. A., Lubis, Z., Hamdallah, M. E. (2015). Determinants of Bank Selection Criteria's in Relation to Jordanian Islamic and Conventional Banks. International Journal of Economics, Commerce and Management. Vol. 3(10): 294-306.

Zaher, T. S., \& Hassan, M. K. (2001). A Comparative Literature Survey of Islamic Finance and Banking. Financial Markets, Institutions \& Instruments. Vol. 10: 155-199.

Zubair, H. M., \& Chaudhary, N. G. (2014). Islamic Banking in Pakistan: A Critical Review. International Journal of Humanities and Social Science. Vol. 4(2): 161-176. 